DOI: 10.35784/IAPGOS.131

\title{
A NEW CONCEPT OF DISCRETISATION MODEL FOR IMAGING IMPROVING IN ULTRASOUND TRANSMISSION TOMOGRAPHY
}

\author{
Tomasz Rymarczyk $^{1,2}$, Krzysztof Polakowski ${ }^{3}$, Jan Sikora ${ }^{1,2}$ \\ ${ }^{1}$ Research \& Development Centre Netrix SA, Lublin, Poland, ${ }^{2}$ University of Economics and Innovation in Lublin, Faculty of Transport and Informatics, Lublin, Poland, \\ ${ }^{3}$ Warsaw University of Technology, Warsaw, Poland
}

Abstract. In this paper a new version of discretisation model for Ultrasonic Transmission Tomography is presented. The algorithm has been extensively tested for synthetic noisy data on various configurations of internal objects. In order to improve the imaging quality, the pixels/voxels have been enlarged compared to the figures inscribed in pixels/voxels however no more than figures described on the standard square pixels or cubic voxels. The proposed algorithm provides better quality of imaging.

Keywords: Ultrasound Transmission Tomography, image reconstruction, constrained optimisation, circular pixels, spherical voxels

\section{NOWA KONCEPCJA DYSKRETYZACJI MODELU CELEM PODNIESIENIA JAKOŚCI OBRAZOWANIA W TRANSMISYJNEJ TOMOGRAFII ULTRADŹWIĘKOWEJ}

Streszczenie. W tym artykule zaproponowano nowa wersję dyskretyzacji modelu dla Ultradźwiękowej Tomografii Transmisyjnej. Przedstawiony algorytm byt wszechstronnie przetestowany dla danych syntetycznych zaszumionych dla różnych konfiguracji obiektów wewnętrznych. W celu poprawienia jakości obrazowania, piksele/woksele zostaty powiększone $w$ stosunku do figur wpisanych $w$ piksele/woksele, jednak nie więcej niż figury opisane na standardowych kwadratowych pikselach lub sześciennych wokselach. Proponowany algorytm zapewnia lepsza jakość obrazowania.

Słowa kluczowe: Transmisyjna Tomografia Ultradźwiękowa, obrazowanie, optymalizacja z ograniczeniami, piksele kołowe, woksele kuliste

\section{Introduction}

The discretisation model with circle space elements $[12,14,15]$ instead of classical square pixels or cuboid voxels simplifies numerical calculations on the one hand [13], but on the other hand causes complications. Under assumption that the rays have infinitely thin, some rays passing through square pixels or cubic voxels do not pass through their circular - spherical equivalents.

The area fill factor for the entered figures is suitable for $2 \mathrm{D}$ and 3D spaces;

$$
\mathrm{W}_{2 \mathrm{D}}=\pi / 4 \text { and } \mathrm{W}_{3 \mathrm{D}}=\pi / 6
$$

So in the case of $2 \mathrm{D}$ space less than $80 \%$ of the area is covered with circular pixels and for 3D space less than $55 \%$ of the volume is covered with a new voxels. It is obvious that this situation is a source of imaging errors.

This defect is especially visible for $3 \mathrm{D}$ space. To alleviate this problem, one can slightly enlarge the circular pixels or spherical voxels, moving from the figures inscribed to the figures described (see Fig. 1 and Fig. 2). The visualisation presented in Fig. 1 was made using isometric axonometry. This figure shows a cubeshaped voxel and the spheres inscribed and described on it with the common points of the projection ray and the voxel walls. Those common points were named Pc (with standard cuboid like voxel), PSo with sphere described and PSi with sphere inscribed.
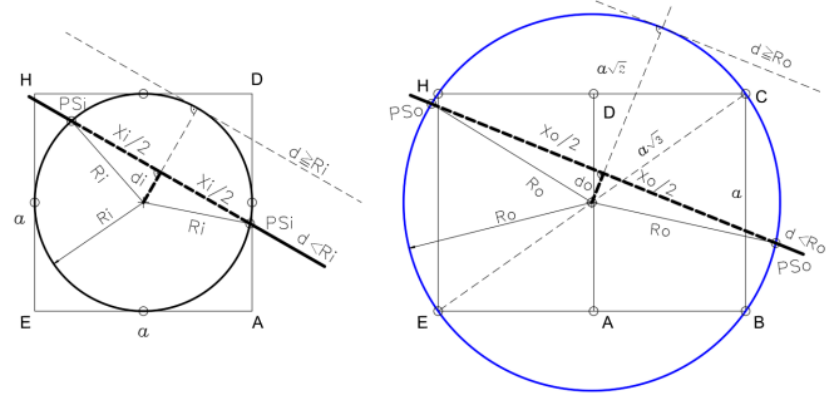

Fig. 1. A projection of a sphere inscribed in a cube and described on a cube

The radius of the sphere described $R_{0}$ is sqrt(3) times greater than the radius of the sphere inscribed $R_{1}$ in a cubic voxel (see Fig. 1).
If instead of the inscribed figures, the figures described were applied, then the whole space would be filled, but unfortunately the voxels would overlap, causing additional difficulties and errors resulting from this fact.

Therefore, a compromise solution was proposed consisting in increasing the radius in such a way as to fill the largest possible area of the imaged space, while at the same time the surface/volume of the overlapping pixels/voxels is as small as possible. The value of the radius increased by about $30 \%$ in relation to the inscribed radius was determined by means of a numerical experiment. Then the fill factor of the area for figures with radii increased by $30 \%$ in relation to the entered figures is respectively for $2 \mathrm{D}$ and $3 \mathrm{D}$ spaces:

$$
\mathrm{W}_{2 \mathrm{D}}=\pi / 4 \cdot 1.3^{2}=1.327 \text { and } \mathrm{W}_{3 \mathrm{D}}=\pi / 6 \cdot 1.3^{3}=1.15
$$

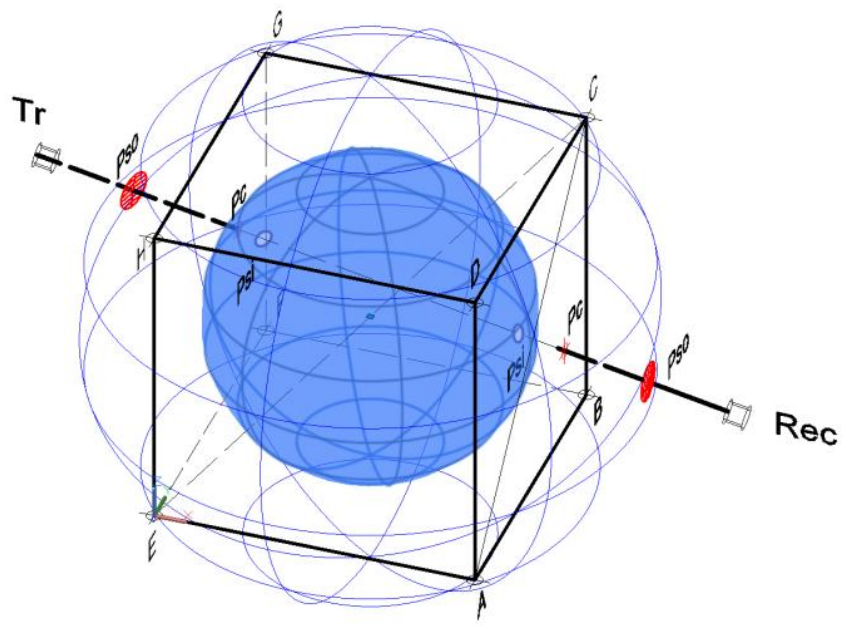

Fig. 2. Replacement of a cubic voxel with a sphere inscribed in a cube or described on a cube

\section{Modifications in 2D space}

In the 2D space, the square pixel has been replaced by a circular pixel inscribed in the square and then described on the square. In order make the figures clear only the first raw was shown in Fig. 3. The arc in this figure represent the edge of the region under consideration. 


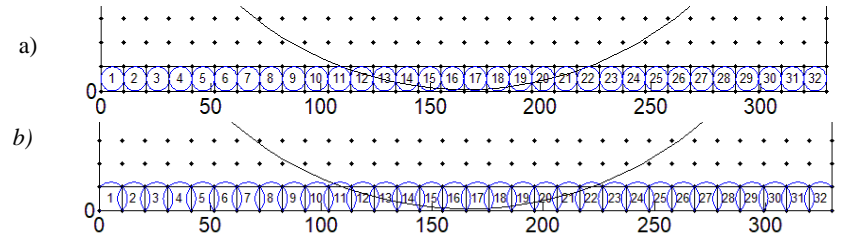

Fig. 3. Only the first row of square pixels replaced by: a) circular pixel inscribed, b) circular pixel described

In order to check the proximity effect, two closely placed objects were considered, presented in Fig. 4. The 32 sensors fixed on the perimeter of the region were considered as it was done in our previous works see for example [13]. The Algebraic Reconstruction Technique (ART) was used to formulate the system of algebraic equations [1-6, 8-10] solved by Singular Value Decomposition (SVD) [7]. The distribution of the singular values of the coefficient matrix is shown in Fig. 4b [7]. For both cases, i.e. the standard circular pixel and the increased circular pixel, the distribution practically did not differ much.

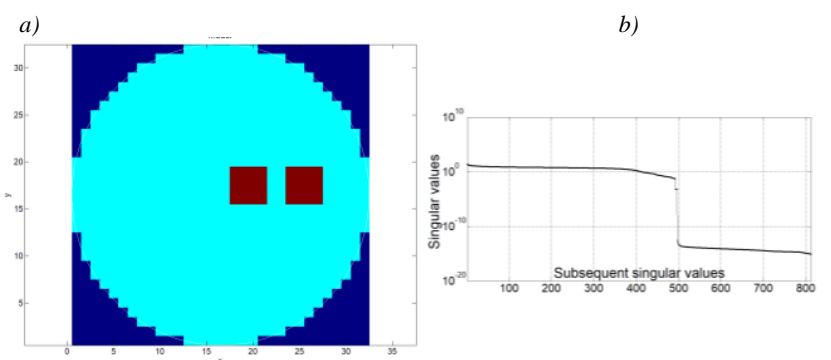

Fig. 4. Image of the model $b$ ) singular value distribution

In previous works $[11,13]$ for noise free signal correctness of the novel discretisation was proved. To demonstrate the advantages of pixel enlargement, a synthetic signal with 5\% noise was considered, as shown in Fig. 5.

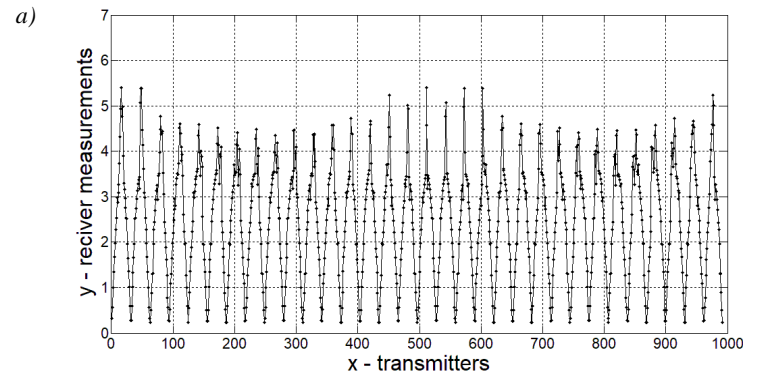

b)

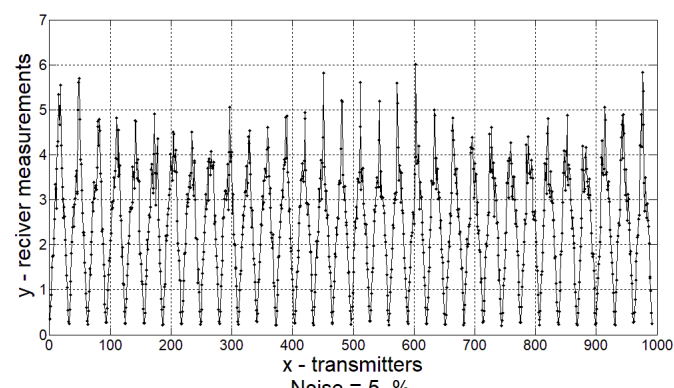

c)

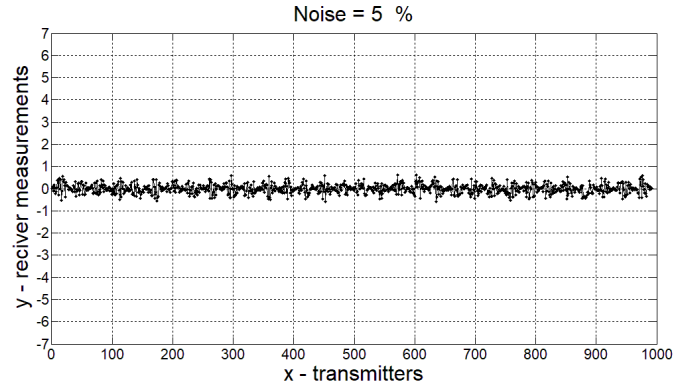

Fig. 5. "Measured" signal: a) noisy free, b) the signal with 5\% noise, c) the noise
Imaging results for a standard circular pixel are presented in Fig. $6 \mathrm{a}$ and for a circular pixel enlarged in Fig. $6 \mathrm{~b}$.

In both cases, the image is acceptable, however, the pixel enlargement has improved the quality of imaging, in particular the pixel closer to the centre of the considered area, where the sensitivity of the material factor to the measuring signal is the lowest.

The obtained results may not be spectacular, which could be explained by a much higher fill factor for $2 \mathrm{D}$ space than for $3 \mathrm{D}$ space in case of inscribed pixels (see eq. 1). For this reason, the authors believe that this method will be particularly useful in matters of 3D space.

a)

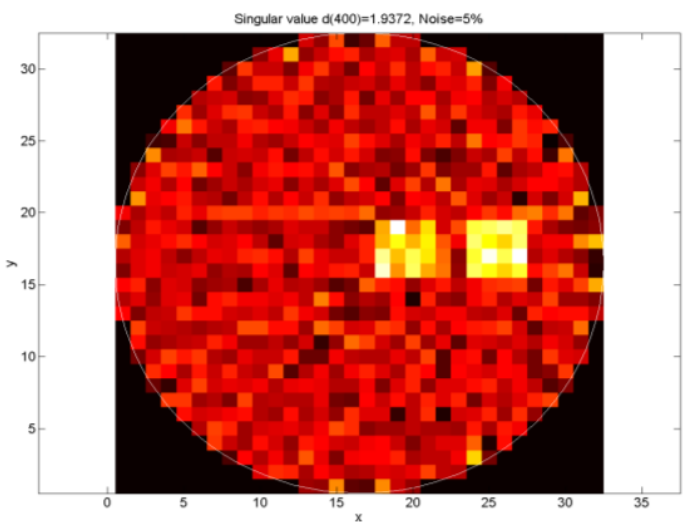

b)

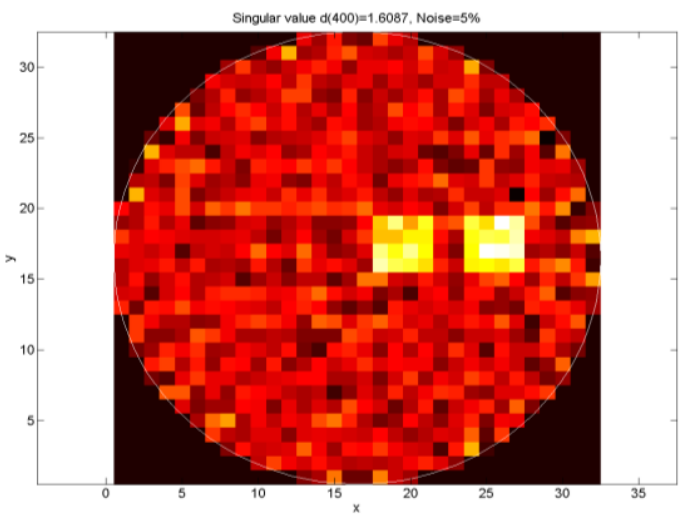

Fig. 6. Imaging results: a) for a circular pixel inscribed, b) for a circular pixel described on a square pixel

\section{Modifications in 3D space}

In 3D space as shown in Fig. 7, the replacement of cubic voxels with spherical voxels causes that some voxels in the path of certain rays may be omitted. a)

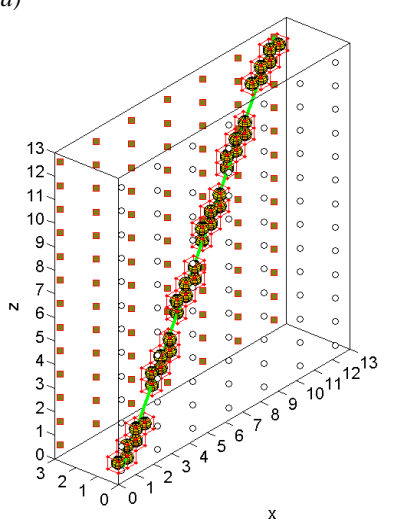

b)

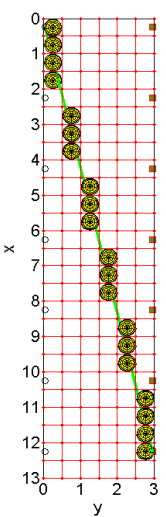

Fig. 7. Missing spherical voxels in the path of the selected ray

This problem may be alleviated by an enlarged radius, but this will result in overlapping of adjacent spherical voxels as shown in Fig. 8. 
a)

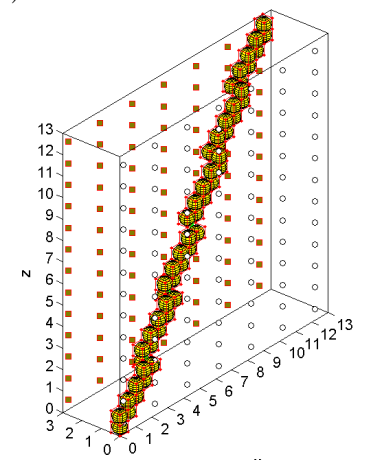

b)

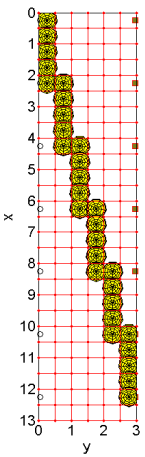

Fig. 8. Enlarged voxels along the selected ray

Let's consider a single object placed asymmetrically inside a rectangular container as shown in Fig. 9a. The sixty and four sensors were placed on the edge of the container in two layers (see Fig. 9b). To study the effect of sensor placement on imaging quality, different sensor spacing was placed in the upper and lower layers (see Fig. 9a and Fig. 9b). a)

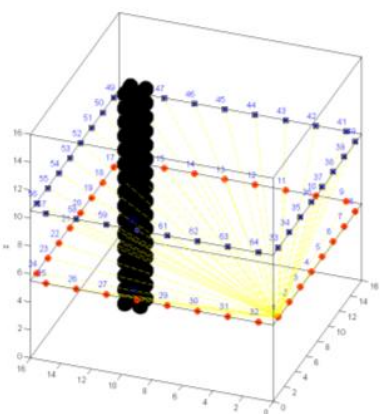

b)

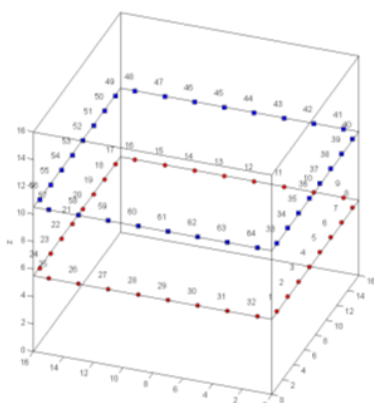

Fig. 9. Container with an internal object and two layers of sensors on its walls, the rays radiating from the first sensor are marked in yellow

To facilitate imaging, the ratio of background to material factor is 1:10 (see Fig. 10). In the same drawing, the material factor distribution is depicted in the middle of the container height.

Numerical experiments are designed to examine the effect of overlapping voxels on imaging results for transmission ultrasonic tomography in the case of synthetic data.

As can be seen in Fig. 11, the structure of the coefficient matrix changed slightly in favour of enlarged voxels, since the pseudo-order of the matrix [7] increased (see Fig. 11b).

As shown in Fig. 12 and Fig. 13 as a result of imaging, a view was obtained only of the part of the model that was in the space covered by the sensors located on the edge of the volume.

For voxels enlarged by about $30 \%$, we see, especially in the colour map image (see Fig. 13). Clear improvement of the imaging quality could be observed. In addition, due to the change in the volume of the voxel, the matrix pseudo-order increased so that it was possible to reject 56 singular values less than for inscribed voxels $[7,11]$.
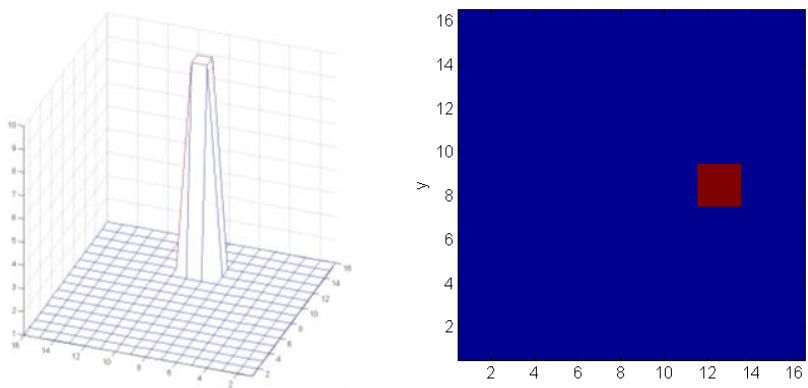

Fig. 10. In the middle of the tank height, its cross section is presented in $3 D$ and as a coloured map
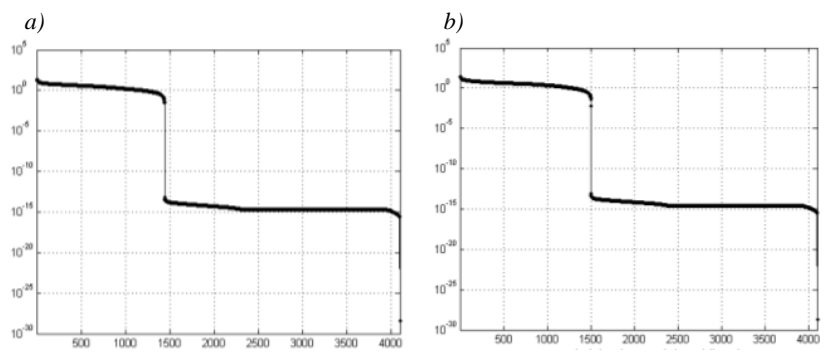

Fig. 11. Distribution of the singular values (vertical axis) versus subsequent singular values: a) for standard spherical voxels and b) enlarged radius of the spherical voxels
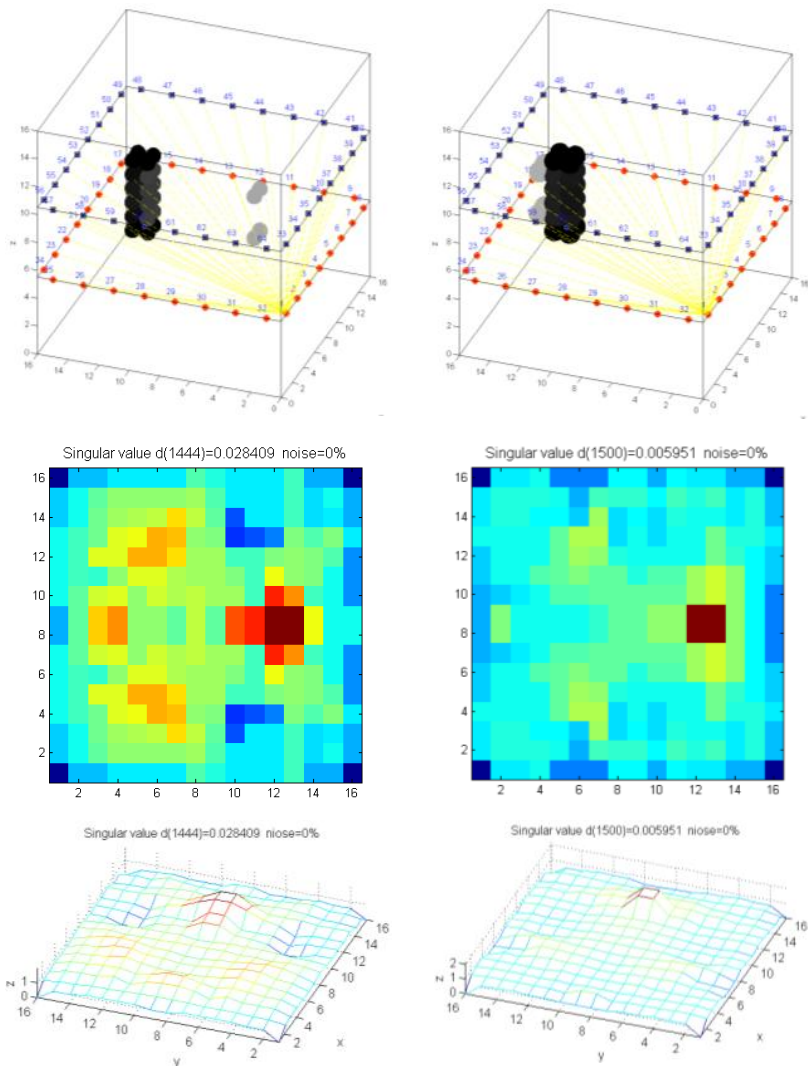

Fig. 12. Imaging results for a spherical voxel inscribed in a cubic voxel

Fig. 13. Imaging results for a spherical voxel radius increased by $30 \%$
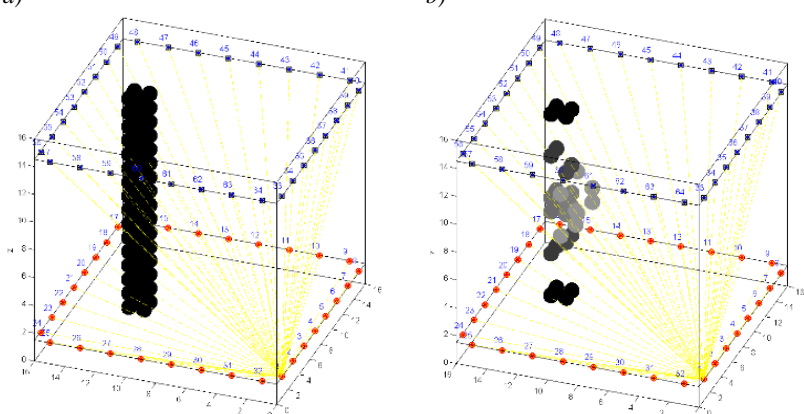

d)
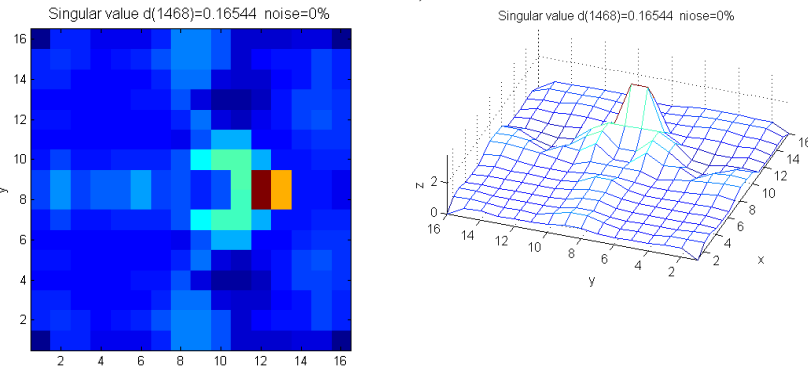

Fig. 14. Influence of spacing between sensor layers on imaging quality 
The greater the distance between the sensor layers, the greater the length of the imaged internal object (see Fig. 14b), but the imaging quality deteriorates (see Fig. 14c and compare with Fig. 13)

In Fig. 14b there are significant gaps in the imaging of the internal object. But as the voxel radius is enlarged (compare Fig. 14a and Fig. 15a), the image quality has improved (compare Fig. 14b and Fig. 15b).

At the same time, an increase in the sensitivity of imaging quality to the choice of matrix pseudo-order can be observed (see Fig. $14 \mathrm{c} \& \mathrm{~d}$ and Fig. $15 \mathrm{c} \& \mathrm{~d}$ ). a)

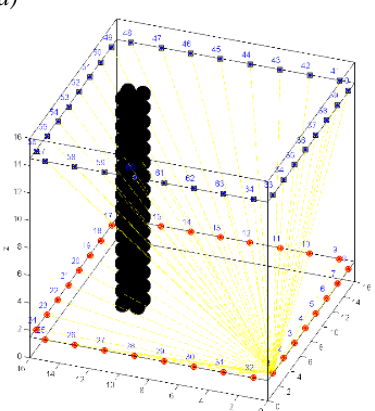

c)

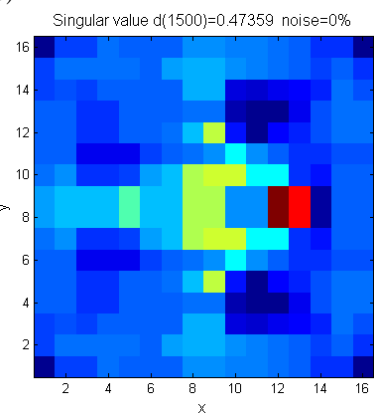

b)

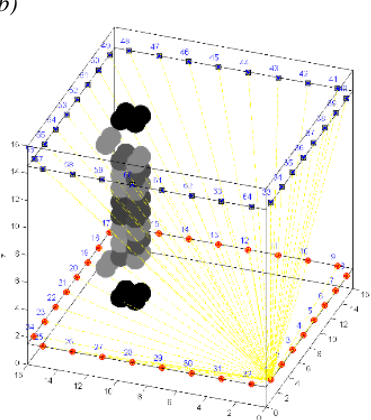

d)

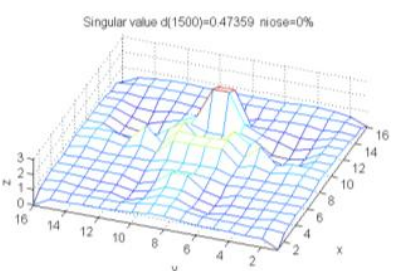

Fig. 15. Influence of spacing between sensor layers on imaging quality

\section{Conclusion}

In this paper a new algorithm for Ultrasound Transmission Tomography was presented. Based on experiments with synthetic noisy data conclusion can be stated as follows:

1. The algorithm with overlapped pixels/voxels provides stable and precise images,

2. For 2D space the results for enlarged pixels are not so impressive since the fill coefficient is much higher (see eq. 1) than for 3D space. So, there is not much space for improvement of ART method in this case.

3. Scale of enlargement of the radiuses for the pixels or voxels depends on the object or objects inside of the region and must be carefully selected depending on the case.

The authors would like to state that all figures were drawn with the aid of MATLAB [16].

\section{References}

[1] Bartušek K., Drexler P., Fiala P., et al.: Magnetoinductive Lens for Experimental Mid-field MR Tomograph. Progress in Electromagnetic Research, Cambridge, 5-8 July 2010, 1047-1050.

[2] Dušek J., Hladký D., Mikulka J.: Electrical Impedance Tomography Methods and Algorithms Processed with a GPU. PIERS Proceedings (Spring) 2017 $1710-1714$.

[3] Kak A. C., Slaney M.: Principles of Computerized Tomographic Imaging. IEEE Press, New York 1999.

[4] Kłosowski G., Rymarczyk T.: Using Neural Networks and Deep Learning Algorithms in Elecrical Impedance Tomography. Informatyka, Automatyka Pomiary w Gospodarce i Ochronie Środowiska - IAPGOS 3/2017, 99-102.

[5] Kłosowski G., Rymarczyk T., Gola A.: Increasing the Reliability of Flood Embankments with Neural Imaging Method. Applied Sciences 8(9)/2018, 1457.
[6] Koulountzios P., Rymarczyk T., Soleimani M.: Ultrasonic Tomography for automated material inspection in liquid masses. 9th World Congress on Industrial Process Tomography, Bath, Great Britain, 2-6 September 2018.

[7] Lawson Ch. L., Hanson R. J.: Solving Least Squares Problems. Classics in Applied Mathematics 15/1995.

[8] Mikulka J.: GPU-Accelerated Reconstruction of T2 Maps in Magnetic Resonance Imaging. Measurement Science Review 4/2015, 210-218.

[9] Ming Y., Schlaberg H. I., Hoyle B. S., Beck M. S., Lenn C.: Real-Time Ultrasound Process Tomography for Two-Phase Flow Imaging Using a Reduced Number of Transducers. IEEE Transactions on Ultrasonics, Ferroelectrics, and Freq. Control 46(3)/1999.

[10] Opieliński K. J., Gudra T.: Ultrasonic Transmission Tomography in Industrial and Biological Tomography: Theoretical Basis and Applications. Electrotechnical Institute, 2010, 265-338.

[11] Rymarczyk T.: Tomographic Imaging in Environmental, Industrial and Medical Applications. Innovatio Press Publishing Hause, 2019.

[12] Rymarczyk T., at all.: Sposób i układ do prowadzenia pomiarów w elektrycznej tomografii pojemnościowej. Patent P.418304, data zgłoszenia: 12.08.2016.

[13] Rymarczyk T., Sikora J., Polakowski K., Adamkiewicz P.: Efektywny algorytm obrazowania w tomografii ultradźwiękowej i radiowej dla zagadnień dwuwymiarowych. Przegląd Elektrotechniczny 94(6)/2018, [DOI: 10.15199/48.2018.06.11].

[14] Smolik W.: Forward Problem Solver for Image Reconstruction by Nonlinear Optimisation in Electrical Capacitance Tomography. Flow Measurement and Instrumentation 21/2010, 70-77.

[15] Soleimani M., Mitchell C. N., Banasiak R., Wajman R., Adler A.: Fourdimensional electrical capacitance tomography imaging using experimental data. Progress in Electromagnetics Research 90/2009, 171-186.

[16] http://www.mathworks.com/products/matlab/ (access: June 2018).

Ph.D. Eng. Tomasz Rymarczyk

e-mail: tomasz@ rymarczyk.com

$\mathrm{He}$ is the director in Research and Development Centre in Netrix S.A. and the director of the Institute of Computer Science and Innovative Technologies in the University of Economics and Innovation, Lublin, Poland. He worked in many companies and institutes developing innovative projects and managing teams of employees. His research area focuses on the application of non-invasive imaging techniques, electrical tomography, image reconstruction, numerical modelling, image processing and analysis, process tomography, software engineering, knowledge engineering, artificial intelligence and computer measurement systems.

ORCID ID: 0000-0002-3524-9151

\section{D.Sc. Eng. Krzysztof Polakowsk}

e-mail: kp@zkue.ime.pw.edu.pl

Krzysztof Polakowski graduated from Warsaw University of Technology Faculty of Electrical Engineering. During the last year of his studies He was employed in the department of Electrical Machines of the WUT, where he defended his PhD and DSc degree. His scientific interest concentrated on 3D modelling with the aid of CAD and also on electro-mobility. Also he is interested in tomography application in the car industry. He is cofounder of specialisation devoted the Car Electricity in Warsaw University of Technology. ORCID ID: 0000-0002-2301-4910

\section{Prof. Jan Sikora \\ e-mail: sik59@wp.pl}

Prof. Jan Sikora (Ph.D. D.Sc. Eng.) graduated from Warsaw University of Technology Faculty of Electrical Engineering. During 44 years of professional work he has proceeded all grades, including the position of full professor at his alma mater. Since 1998 he has worked for the Institute of Electrical Engineering in Warsaw. In 2008, he has joined Electrical Engineering and Computer Science Faculty in Lublin University of Technology. During 2001 2004 he has worked as a Senior Research Fellow at University College London in the prof. S. Arridge's Group of Optical Tomography. His research interests are focused on numerical methods for electromagnetic field. $\mathrm{He}$ is an author of 8 books and more than 180 papers published in the international journals and conferences.

ORCID ID: 0000-0002-9492-5818
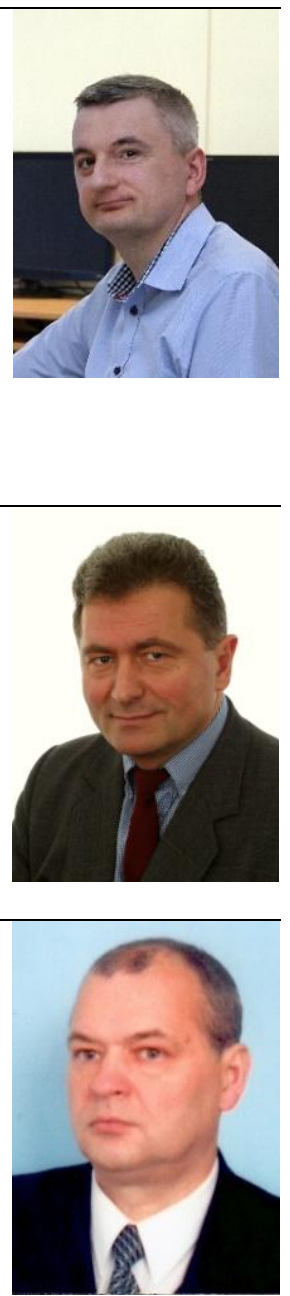

otrzymano/received: 10.09 .2019 przyjęto do druku/accepted: 06.12.2019 